\title{
obituary
}

\section{M. S. Watson}

Professor D. M. S. Watson, FRS, who died on July 23 , aged 87 , was trained at the University of Manchester as a chemist and geologist, but started research in palaeontology. His first palaeobotanical publication appeared when he was twenty and the second (jointly with Marie C. Stopes) was published by the Royal Society only a year later. His early papers include descriptions of a fossil king-crab and the loops of a brachiopod, and within five years of entering vertebrate palaeontology he had published on fossil fish, amphibians, rhynchosaurs, plesiosaurs, crocodiles, chelonians and mammal-like reptiles.

$\mathrm{He}$ developed many of these interests in later years, and in particular began to ask two questions: how did it work and why did it change? By so doing he joined Abel as one of the pioneers of palaeobiological thought, and became a leader in his field by the age of 30 . Much of Watson's work was based on his own collecting in South Africa and he wrote several papers on Karroo stratigraphy. $\mathrm{He}$ was soon recognised as an authority on the mammal-like reptiles, and he began to build up his experience of labyrinthodont amphibians and eotylosaurs, while exploring (jointly with Hankin) the flight of pterodactyls.

Watson was at his greatest in the period between the two World Wars, and his papers on the structure, evolution and origin of the Amphibia stand out as classics. He was appointed to the Jodrell Chair of Zoology and Comparative Anatomy at University College, London in 1921, elected Fellow of the Royal Society in 1922, gave their Croonian Lecture in 1924 and the Romanes Lecture in 1928.

D. M. S. was particularly interested in missing links in the evolutionary record because they held promise of an opportunity to study the functional aspects of transition from one mode of life to another. His quest to fill the structural gap between jawless and jawed fish led to his recognition of the aphetohyoid grade in acanthodians and, although his interpretation has been doubted, his thorough study of this difficult material remains a masterpiece. Other topics which he explored include the evolution of the mammalian ear, the primitive tetrapod limb, the structure of the monotreme skull and fossil coelacanths. For many years Watson was aided in his work by Miss Joyce Townend whose excellent illustrations grace his publications.

By present standards Watson's mechanical preparation of fossils was relatively crude, but his training in geology ensured an ability to visualise three dimensional structure from a series of broken surfaces, and he could break a rock in just the right place to confirm his expectations. He was not a writer of textbooks and communicated best through his lectures, during which he radiated enthusiasm. The spirit of these is captured in Paleontology and Modern Biology, which contains the Silliman Memorial Lectures, essentially as they were delivered at Yale in 1937. Another fine performance was his lecture on Pterodactyls, which he gave on several occasions but never published.

On the personal side, D. M. S. sometimes seemed slightly reserved (he had a charmingly gentle relationship with his wife) but he always found time to listen to his research students and he was tolerant of their inexperience.

\section{Announcements}

\section{Appointments}

Major-General Sir Leonard Atkinson, $\mathrm{KBE}$, has been elected the new chairman of the Council of Engineering Institutions.

\section{Awards}

The 1973 International Health Foundation Award for papers on Diagnostic $X$ ray exposure and the human embryo will go to $\mathrm{Dr}$ Willem Herstel of the Department of Radiology, University Hospital, Leiden.

\section{Errata}

IN the article 'Alteration in Heterocyst Pattern of Anabaena produced by 7 Azatryptophan' by G. J. Mitchison and Michael Wilcox (Nature new Biol., 246 , 229 ; 1973) the diagram captioned 7azatryptophan shows tryptophan and not the 7 -aza derivative. The nitrogen was inadvertently replaced by a carbon during preparation for the printer.

In the article 'Formation of Lunar Carbide from Lunar Iron Silicates' by C. T. Pillinger et al. (Nature phys. Sci., 245, 3; 1973) Figure 1 legend, lines 4 and 5 should read " ${ }^{36} \mathrm{Ar}$ data from Heymann and coworkers ${ }^{5-8}$ ( $\square$ ) and Bogard and coworkers ${ }^{9-11}(\mathrm{O})$ : ... Paragraph 7 , line 9 should read "at least $10^{2}$ times that necessary for the reaction. Conversely, ...".

In the article "Tetrodotoxin and Cobalt Blockade of Neuroblastoma Action Potentials' by Ilan Spectro, Yosef Kimhi and Phillip G. Nelson (Nature new Biol., 246, 124; 1973) the first line should read 'The mouse C-1300' not 'C-13000'; paragraph 4, line 7 should read 'second, slowly rising peak . . .'; Table 1 legend, line 1 should read $\mathrm{MgCl}_{3}=1 ; \mathrm{CaCl}_{2}=2$ (not $\mathrm{MgCl}_{2}=$ $2)$; ref. 5 was published in 1971 not 1972 , and the last author in ref. 8 is Nirenberg, M., not Ninberg, M.

\section{Reports and Publications}

not included in the Monthly Books Supplement

\section{Great Britain and Ireland}

The Natural Environment Research Council. Publications Series B, No. 7: Research in the Geological Sciences. (A consultative document comprising reports from eleven NERC Geological Sciences Working Parties.) Pp. ii +113 . (London: The Natural Environment Research Council, 1973.) The Natura The Zoological Record. 1970. Vol. 107, Section 16: Amphibia. Compiled by the Staff of the Zoological Society of London. Pp. vi +79 . 26.65 . 1970 Sol. 107, Section 17: Reptitia, Compiled by the £6.65. (London: The Zoological Society of London 1973.)

Scientific Proceedings of the Royal Dublin Society. Series A. Vol. 4, No. 31: Lower Palaeozoic Graptolitic Facies in Ireland and Scotland-Review, Correlation, and Palaeogeography. By J. A. Weir. Pp. 439-460. 75p. Vol. 4, No. 32: Variolitic Lavas from South County Wicklow, Ireland. By J. C Brindley and S. Millan. Pp. 461-469. 75p. Series B. Vol. 3, No. 13: The Medals of the Royal Dublin Society. By Arthur E. J. West. Pp. 165-190+ plates 1-7. fl. Vol. 3 , No. 14. Observations on dumeriliting be west of the Polychaete Platynerels dumerilit on the West Coast of Ireland, By John $\mathbf{P}$. Mercer and J. Dunne. Pp. 191-194+ plate 10. 30p Vol, 3, No. 15: The Natural Mortality of Cabbage Root Fly Eggs in Peatland. By M. F. Ryan and Society, 1973.) 195-199. 20p. (Dublin: Royal Dublin National Physical Laboratory. Corrosion of Metals Nesearch 1924-1968. By Frank Wormwell. Pp. Research 1924-1968. By Frank
xix +73. (London: HMSO, 1973.) 11.65 net. 